\section{ECONOMICS}

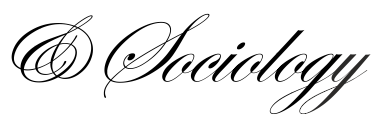

Karacsony, P., Izsák, T., \& Vasa, L. (2020). Attitudes of Z generations to job searching through social media. Economics and Sociology, 13(4), 227-240. doi:10.14254/2071-789X.2020/13-4/14

\title{
ATTITUDES OF Z GENERATION TO JOB SEARCHING THROUGH SOCIAL MEDIA
}

\section{Peter Karácsony \\ J. Selye University, \\ Slovakia \\ E-mail:karacsonyp@,ujs.sk \\ ORCID 0000-0001-7559-0488}

Tilla Izsák

J. Selye University,

Slovakia

E-mail:124278@student.ujs.sk.

László Vasa

Széchenyi István University,

Hungary

E-mail:vasalaszlo@gmail.com

ORCID 0000-0002-3805-0244

Received: October, 2019

1st Revision: September, 2020

Accepted: December, 2020

DOI: $10.14254 / 2071-$

789X.2020/13-4/14

JEL Classification: M12, M52, M59
ABSTRACT. Social media is a relatively new player in the online labour market, with an increasingly important role among the younger generation. The aim of this research was to assess the job search habits and opinions of young people, particularly university students. The survey was conducted on the students in Austria and Hungary via email and social media in March 2020. In analysing the results, we look at what today's younger generation is focusing on when looking for a job, and how companies adapt to the new situation that has been brought about by the widespread use of social media. The purpose of this study is to examine the trends in online job search among "Generation Z". As the survey shows, Generation Z prefers online job search over older methods just as they spend a huge portion of their free time on social media platforms. The data shows that while traditional types of recruitment such as newspaper advertising are on the decline, the function of social media is no longer simply immersed in entertainment and chat, but also spread actively on recruitment and human resources management.

Keywords: digitalisation, social media, Facebook, job search, Z generation

\section{Introduction}

In recent years, job search habits and job postings have changed radically (Jansen et al., 2005). Before the World Wide Web became so commonplace, the usual method was to deliver application documents by mail or in person. Companies mostly tried to recruit using printed media, posters, or even in person. This has now completely changed because digitalisation has nearly fully replaced the old methods, for both the applicant and the job provider (Sullivan, 2013). Nowadays, jobseekers try to search for jobs mainly through online portals or social networks and they mostly contact the company digitally, using an electronic application form or via e-mail (Petschar \& Zavrel, 2016; Lenart-Gansiniec, Sułkowski, 2020). 
The main purpose of our research was to strengthen our presumption that the labour market is now adapting to the needs of new generations and is trying to reach young people via new platforms and also that social networks have become unavoidable as a method of recruitment.

\section{Literature review}

\subsection{Digital Presence}

With the introduction of online job portals and social media, recruitment has completely changed: today's younger generations search for a suitable job on the Internet (Beard et al., 2012) due to steep ICT development (Lechman, 2018) and their usage in HRM practices (Bilan et al., 2019). In addition to job portals created for this purpose, social media platforms and applications also play a major role in the job search process. Today's recruitment strategy is personalised and more targeted than ever (Kluemper \& Rosen, 2009). Companies can provide much more information than before. Applicants can even watch promotional videos on YouTube about the company and access websites where they can get information from other applicants and employees, as well as read blogs and opinions about the company that is relevant to them. Under such circumstances, firms need to place great emphasis on developing and continuously updating their own profile (Chapman \& Webster, 2003).

Social media allows a company to search for candidates who are not necessarily looking for work. This is a huge change as in the past it has been very difficult for companies to reach those who are not actively looking for work (Davison et al., 2016). With the increase in widespread usage of the Internet, it has become very easy to get information about a person or a company, so companies also need to constantly monitor what they share and how they advertise themselves as an employer (Slovensky \& Ross, 2012). In addition, it is also important for the jobseeker to consciously manage their own social media profile by paying attention to what they share online, as almost $70 \%$ of recruiters visit the applicant's social media profile, and what they see there influences their decision (Savković et al., 2016).

As of 2020 , more than 4.5 billion people are already using the Internet and, from that, 3.8 billion people are using some form of social media according to the research in the Digital 2020 (datareportal.com, 2020) reports, which also found that almost $60 \%$ of the Earth's population is online and by the middle of the year more than half of its population will be using social media in some form (e.g., Facebook, Twitter, LinkedIn, Pinterest, TikTok, etc.). According to their survey, in 2019 a person would spend an average of 6 hours and 43 minutes online each day. This is 3 minutes fewer than last year's average, but still, if we calculate it, we spend more than $40 \%$ of our time surfing the Internet with 8 hours of sleep. Of that, we spend 2 hours and 24 minutes on some social media interface that $83.7 \%$ of Internet users actively using. Of course, this period varies from country to country. 53\% of our time spent online is done via a smartphone, $44 \%$ via a laptop or desktop computer, $2.7 \%$ via a tablet, and $0.07 \%$ via other means such as a game console. 50\% of mobile Internet is used only for communication applications such as Facebook Messenger or WhatsApp. Facebook is still the most used social media platform with 1.95 billion users. Currently, marketers could reach half of the young adults worldwide (between 18 and 34) through Facebook (Digital 2020).

\subsection{Characteristics of $Z$ generation}

According to Jobvite's research, in 2019, 41\% of the younger jobseekers said that they were looking for job postings mostly on social platforms and younger generations like $\mathrm{Z}$ were 
increasingly preferring online methods and communication. Based on these surveys, $65 \%$ of young workers responded that career-building opportunities are the most important aspects to them when choosing a job. Since we are talking about the present and future generations, we should be aware that their long-term behaviour will determine future trends in recruitment.

Generation Z (1995-2010): They are also called digital natives because they grew up with digital devices from almost infancy (Prensky, 2001). It is natural for them to be able to contact anyone at any time and that most of their friends are online. They share their social life constantly with the public and personal freedom is very important to them. They are not afraid of the transition from "traditional" to "digital" either because they were born into it. They are the world's first global generation (Karacsony, 2019). This means that members of this generation, although living in different parts of the world as a result of globalisation, are affected by the same events and trends. They watch the same movies, listen to the same music, and, perhaps most importantly, they connect with each other through the Internet and social networking sites (McCrindle and Wolfinger, 2010), have the same features of online purchase behaviour (Nikodemska-Wołowik et al., 2019; Victor et al., 2019).

\subsection{Online labour market}

Online job portals have been with us since the 1990s and are widely used nowadays as well (Navickas et al., 2019). The essence of these websites is that the employer places an advertisement with information regarding a vacant position and waits for candidates to apply (Mičík and Mičudová, 2018). Such approach to hiring becomes widespread in business, and in some cases, it can significantly shift business results due to hiring skilled employees via use appropriate channels of communications in recruiting (Bilan et al., 2020). Jobseekers can search based on specified data such as experience, education, language skills, salary, etc. They can upload their CV and cover letter and can easily send their applications for several advertised positions (Suvankulov et al., 2012).

Online social media networks such as LinkedIn, Facebook, and Instagram can be defined as web-based services that allow individuals to create a public or semi-public profile within a limited system and choose a list of users to share their connection with (Nicoli and Papadopoulou, 2017; Mazurek, Korzyński, \& Górska, 2019). The basic features of LinkedIn allow employees and employers to create profiles. Users are able to track companies and search for companies or organisations they are interested in. Recruiters and HR employees are increasingly using LinkedIn to find potential candidates because they can very simply find the users who are relevant to them with keywords and a single click (Fertig, 2013).

Nowadays, social media is also influencing people in their decision making, so it is important that companies use social media as a marketing tool correctly (Maida, 2011; BartosikPurgat, 2019). Companies have to be innovative and develop alternative marketing strategies in order to meet the expectations of young people (Montana and Petit, 2011), which in turn, have further continuation in expectations regarding possibilities of remote work and higher remuneration due to higher technology-based skills' level (Saksiriruthai, 2018). Various online platforms such as social media allow the marketing specialist to obtain additional information about their target market and take advantage of it (Yankow, 2017). Surveys show that companies are increasingly using social networks to screen and select applicants (Stoughton et al., 2013). 


\section{Methodological approach}

\subsection{The aim of the research}

The aim of the research is to: assess the online job search habits of young people belonging to generation Z; explore their expectations and experiences with companies' ads; and to highlight the current importance of social networks for job search and supply. This topic is important in allowing us to be aware of the changes that have taken place in terms of the needs of the new generations, so that we can continue to adapt the supply to the needs and to keep youth unemployment to a minimum. The Internet and online social portals play a huge role in the lives of young generations, so it is important to know their opinions and habits when looking for a job.

\subsection{Data collection methods}

The methodology of the research was implemented through an online survey. The survey consists of 21 questions, which mainly focus on the respondents' opinions and habits in relation to job search via the Internet and social media. There are three types of questions in the questionnaire. Most questions are closed-ended, where the respondents' answers are limited to a fixed set of responses that can be easily used for computer processing. 14 questions had predefined easy-choice options; 4 scaled questions that focus on the respondents' attitudes using a Likert scale; and the rest were short, open-ended questions. The first part of the questionnaire mainly examined the demographic information of the respondents, by age and nationality. The second part is focused on the respondents' "Internet habits" such as how much time they spend online, and the third part assesses their job search methods and experiences.

The survey was conducted in March 2020, mainly with the participation of international students who were students at Johannes Kepler University in Linz and Széchenyi István University in Hungary. The main target audience were members of Generation Z. The questionnaires were distributed to students via e-mail and Facebook. Due to the limited size of the work, only the selected questions will be presented and visualised with diagrams. Percentages are always given by the percentage of people who had completed a given question. Decimal results on the figures have been rounded to whole numbers for easier transparency and illustration.

During the research process, we received 234 responses mostly from university students. In the evaluation process we used only those questionnaires which were fully completed. The respondents' demographics constituted of people from 27 different nationalities, 4 continents (52.6\% European, 34.2\% Asian, 7.7\% American and 5.6\% African) (Figure 1).

Figure 1. Origin of respondents, percentage

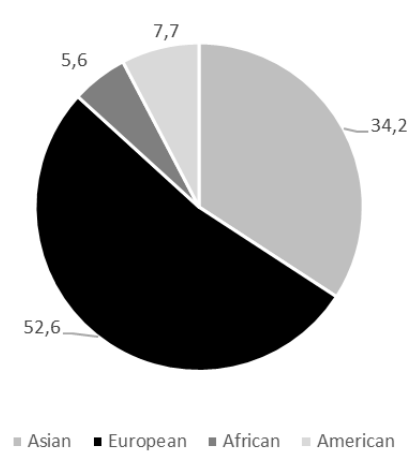

Source: own data 


\subsection{Demographic data of respondents}

The majority of respondents $(84.61 \%)$ were under 25 years old and therefore a member of Generation Z, which greatly contributed to us being able to examine the opinions of this generation. These results are important because we are mostly interested in the views of this age group as they are the ones who will soon graduate from university and enter the workplace. Of these, $35 \%$ were under $20,26.5 \%$ between 21 and 22, $23.1 \%$ between 23 and 24, and $15.4 \%$ 25 years or over (Figure 2).

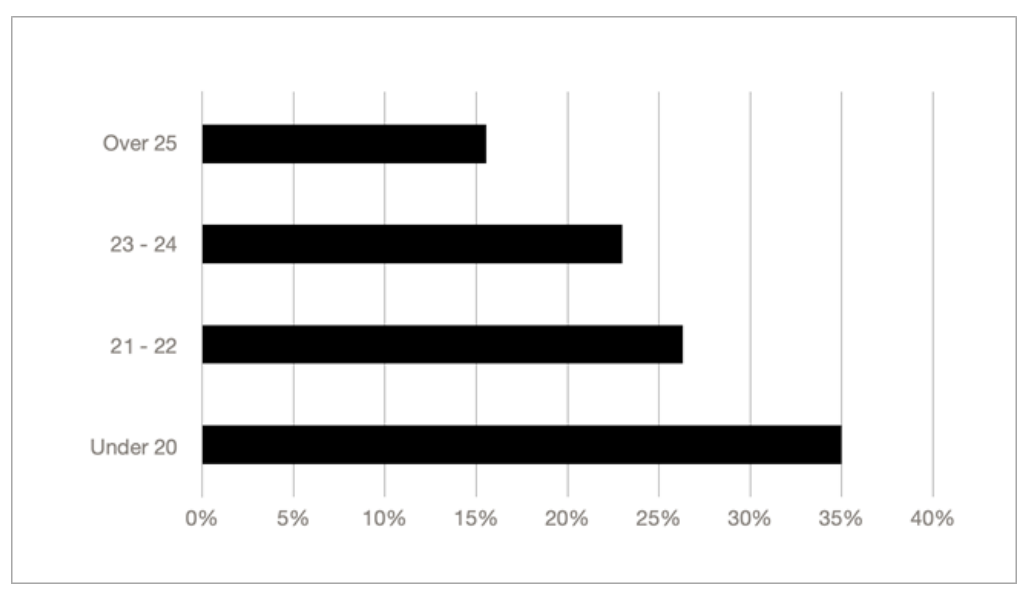

Figure 2. Age of respondents, percentage

Source: own data

\section{Empirical results and discussion}

Technology plays a grand role and shapes the lives of young people all around the world. Generation Z, who were born into the world of the Internet, not only use it to search for information but also to create their own content, such as posting videos on social media platforms - even on a weekly basis (Swartz et al., 2017). In the following Figure 3, we can see how much the respondents consider themselves to be an intensive social media user. This could be assessed using a Likert scale from 1 to 7 , where 1 indicates a passive user and 7 indicates an intensive user. We can see that the majority (79.5\%) gave values ranging from 5 to 7 , they classify themselves rather an intensive user. In addition, $37.2 \%$ of them chose the highest rank (7). Only $3.4 \%$ of the responders chose the lowest rank (1).

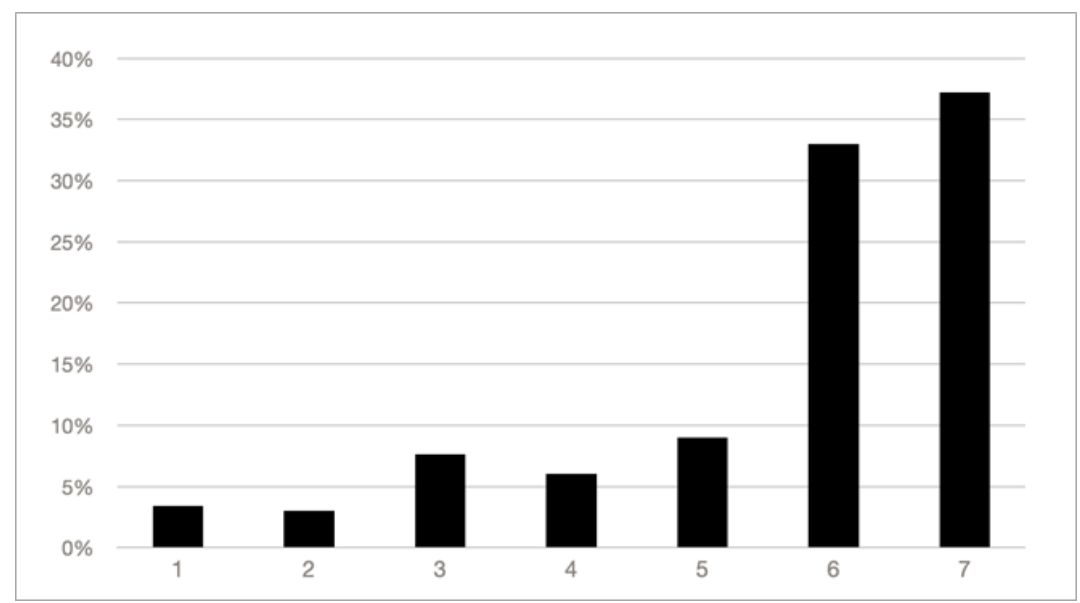

Figure 3. The usage intensity of social media users (1-passive, 7-intensive)

Source: own data 
In figure 4, we compared how many hours per day the respondents spend on social media platforms. The results show that $11.1 \%$ spend more than 6 hours; $17.9 \%$ between 4 and 6 hours; the majority (31.6\%) use it from between 2 to 4 hours; $30.3 \%$ between 1 and 2 hours; and only $9 \%$ use it for less than an hour. These results roughly match the results of Digital 2020, which says people spend an average of 2 hours and 24 minutes a day on social networks.

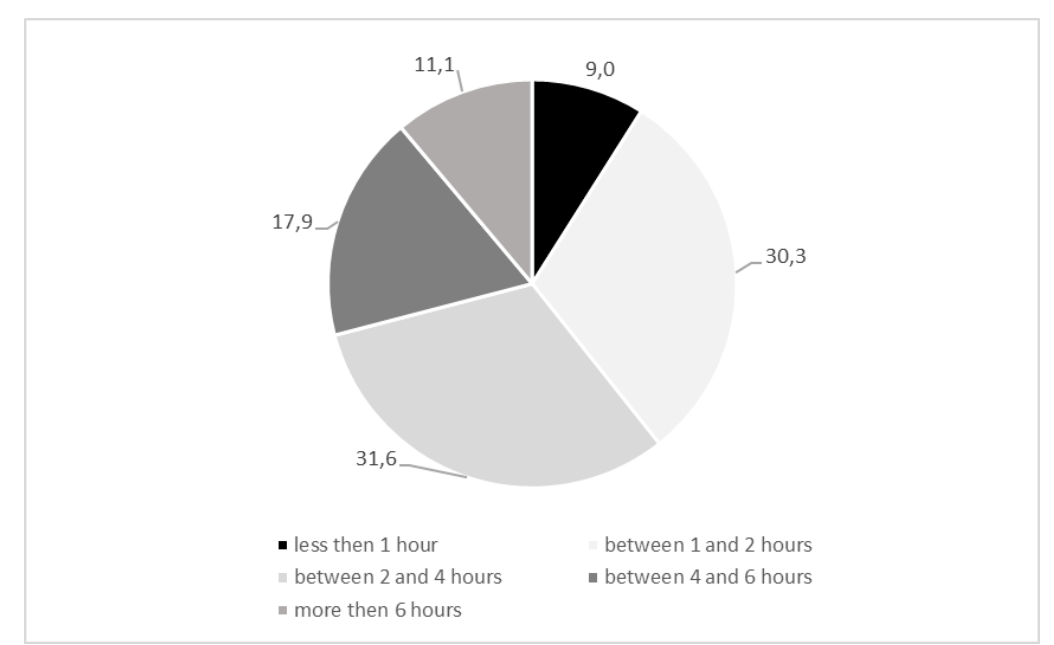

Figure 4. Average time spent on social media per day, percentage

Source: own data

The following figure 5 shows data on the job search habits of respondents. We learned from our responses that they primarily use the Internet to search for jobs. The three most chosen responses were social media $(45.7 \%)$, online job portals $(21.4 \%)$, and the company's website (14.1\%), and through friends and family (10.2\%) These data show that almost half of the respondents (45.7\%) marked social media as a possible method for finding a job. The employment agency received only $5.6 \%$ of responses. On the other hand, the job search in newspaper advertisements is clearly declining, as only $3 \%$ of our respondents would use this method.

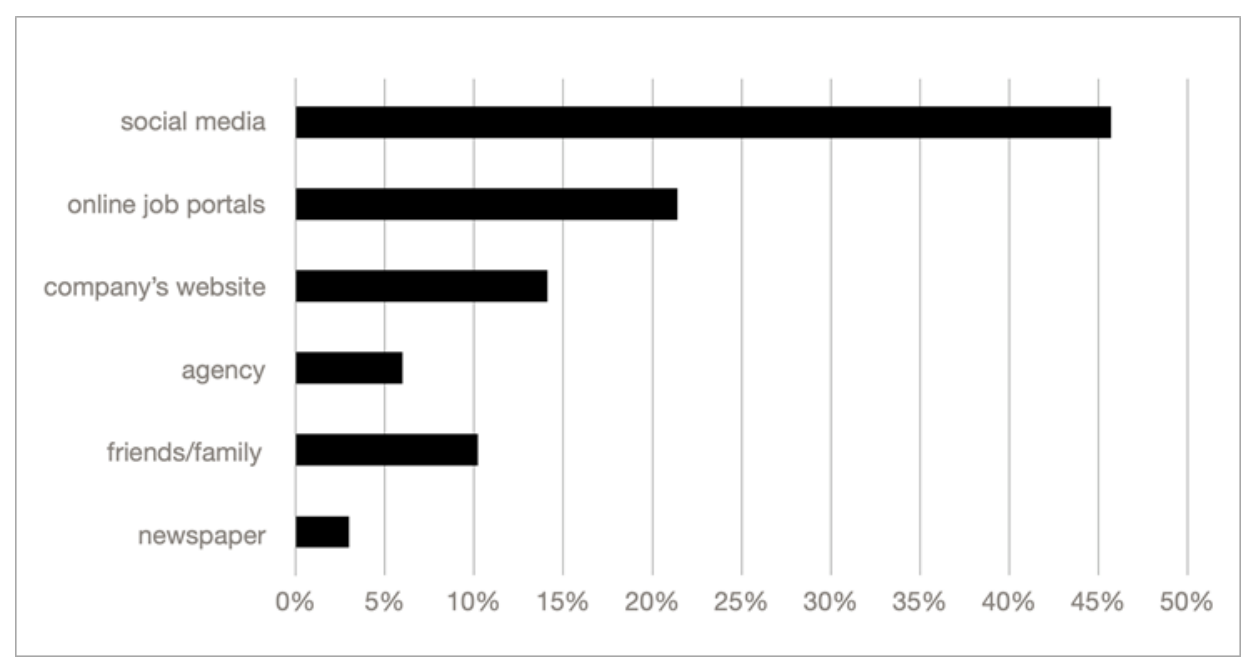

Figure 5. Job searching methods of the respondents, percentage

Source: own data

When asked if they had already received an offer or advertisements through an online job portal, $72 \%$ answered yes, of which $49 \%$ received an offer or an advertisement more than 
once. In addition, $68 \%$ of respondents said they had applied for a job through an online job portal at least once, and $37 \%$ indicated that they had gotten a job that way.

When we asked respondents which social media platform they get the most job offers from, 63\% stated Facebook and 47\% LinkedIn. We also learned from the responses that most of the offers came from Facebook groups that were created for job search and advertising. From this, we can see that more companies, corporations, and even individuals are already using social media to recruit new employees. Furthermore, platforms like Instagram or Twitter don't seem to be really suitable for job searching, but companies use them as a marketing ploy to stay in the public eye and increase their awareness as well as advertise themselves or their products - this is an observation we made during the course of the study.

Figure 6 shows which social networking sites are the most popular among young people. It is important to note that these social media sites can be used mainly for leisure, recreation, chat, games, and even shopping. The figure clearly shows that the most used social media platforms were Facebook (34.4\%), LinkedIn (26.9\%), and Instagram (12.4\%). These social media platforms are the most visited websites in the world (Hootsuite, 2020).

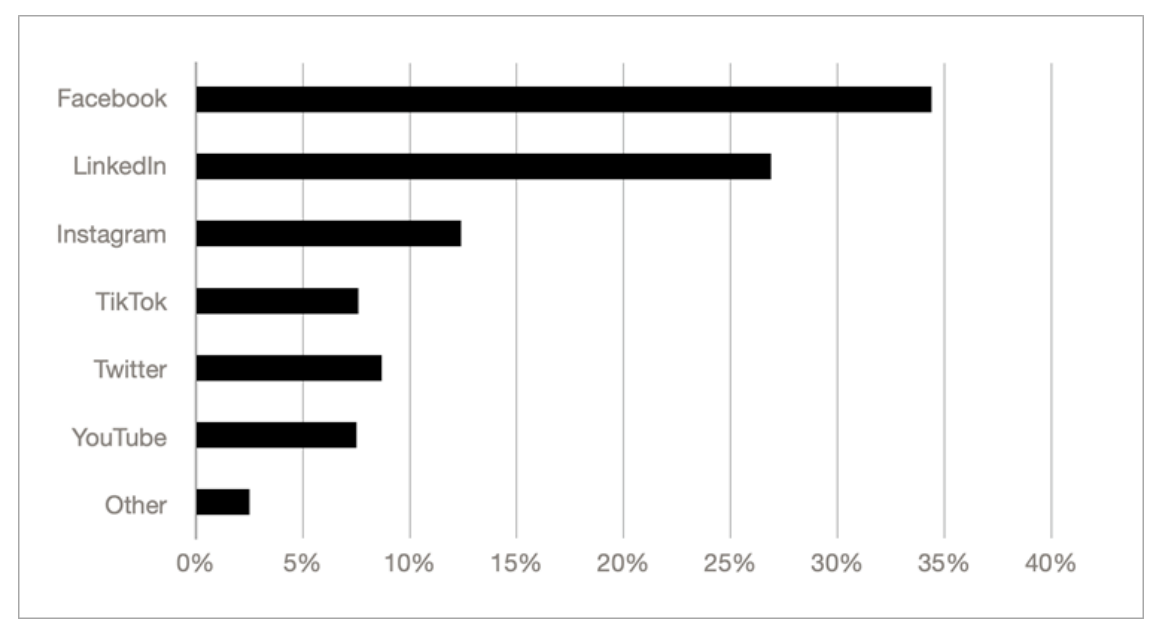

Figure 6. Popularity of different social media platforms, percentage

Source: own data

As it is very easy to access information through the Internet these days, next we will focus on how much this is exploited by young people. One of the survey's closed questions was "Have you ever watched a promo video about a company you were interested in?" where $87 \%$ of respondents answered "yes" and 13\% said "no", and those between the ages of 20 and 22 had the lowest percentage of who had not yet watched such a video (19\%). Finding information is greatly facilitated by the presence of websites such as glassdoor.com, which is designed to allow current or former employees to write anonymous opinions about the company where they work or have worked. This type of information gathering is already very common and does not cause problems for the majority of Generation $\mathrm{Z}$ to do it (Madia, 2011). Employees are increasingly checking online comments before making their final decisions (Stamolampros et al., 2019).

Just as a user needs to pay attention to what they share about themselves on the Internet, the same applies to companies. The difference is that, in the case of companies, emphasis can also be placed on the promotion of the company. This assumption is reinforced by the diagram in the following figure (7), where, with the help of the Likert scale (1-not important, 7-very important), we can see that $46.6 \%$ of the respondents consider the profile of the company and opinions of the other users to be at important to some degree and may affect their decisions. 


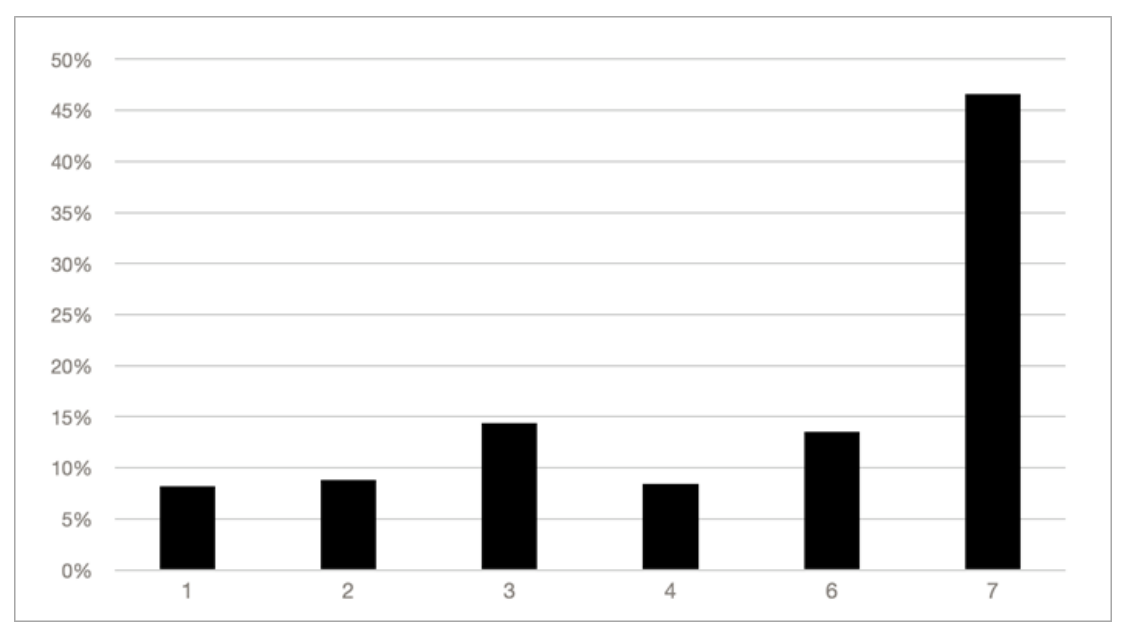

Figure 7. Importance of the company's social media profile, percentage (1- not important, 7- very important)

Source: own data

After that, we wanted to know how reliable social media platforms are. The latter question was open-ended, so that a respondent would be able to briefly explain his or her bad experience. Several classified the following factors as bad experiences: that they never received a response to their application; the constant "bombardment" of e-mails from job portals; and that, in many cases, the job description was very deficient or even untrue. This information gives a good idea of what a company needs to pay attention to, such as providing a more accurate job description of the position being advertised. In addition, there was a single case where the respondent felt that their application had not been accepted due to discrimination.

In Figure 8, the Likert scale shows that participants have a very positive opinion about the reliability of online job search (1-unreliable, 7 -absolutely reliable). $67.1 \%$ of respondents chose the higher ranks on the scale (5-7), according to which online job search is rather reliable. However, interestingly, the majority of votes peak at 5 points, which indicates that $30.3 \%$ of respondents, although they consider online job search reliable, would not give it a value of 7 because of their experience or caution.

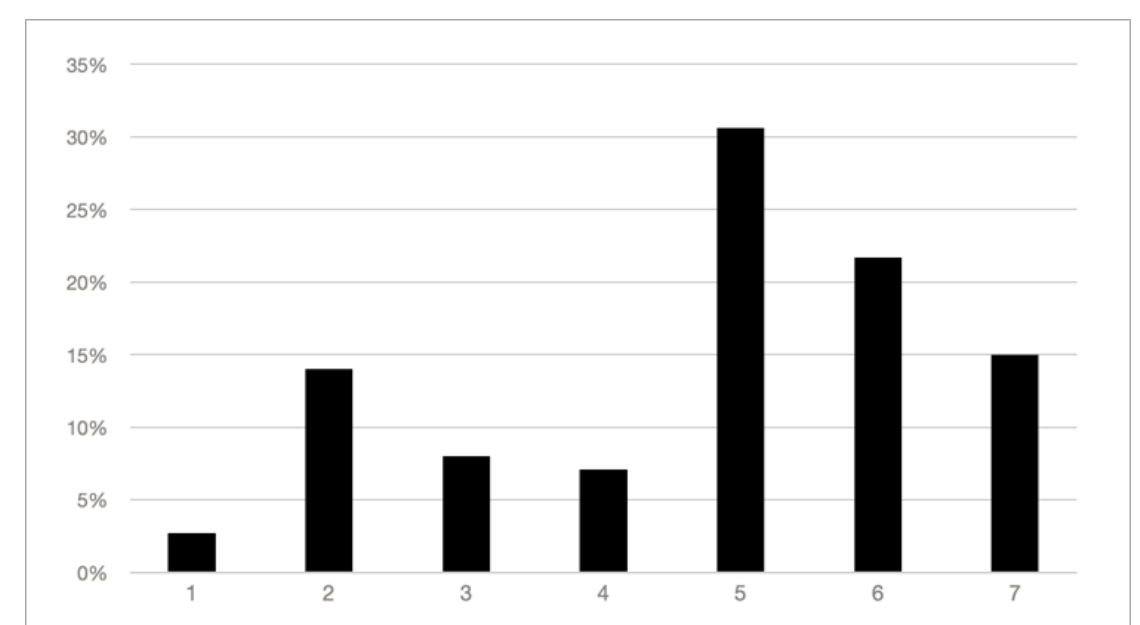

Figure 8. Respondents' opinions about the reliability of the online job search, percentage (1-unreliable, 7-absolutely reliable)

Source: own data 


\subsection{Application of multiple linear regression analysis}

Based on the literature review and previous research, we have identified the following hypotheses to justify our research results:

H1: There is a significant relationship between the use of social media and the job search habits of Generation Z

H2: There is a significant relationship between the reliability of a company profile and the choice of a workplace for Generation Z

To verify our hypotheses, we performed a regression analysis.

According to research in the literature, the generation $\mathrm{Z}$ prefer the opportunities provided by social media to search for jobs. To prove this, we performed a regression analysis of the data obtained from our questionnaire survey, where the independent variable was the use of social media, while the dependent variable was the job search habits of the generation $\mathrm{Z}$. The results obtained are detailed in Table 1 below.

Table 1. Regression model of hypothesis 1

\begin{tabular}{|c|c|c|c|c|c|c|c|c|c|c|}
\hline \multicolumn{11}{|c|}{ Model Summary $^{\text {b }}$} \\
\hline & & & & & \multicolumn{5}{|c|}{ Change Statistics } & \multirow[b]{2}{*}{$\begin{array}{l}\text { Durbin- } \\
\text { Watson }\end{array}$} \\
\hline Model & $\mathrm{R}$ & R Square & $\begin{array}{l}\text { Adjusted } \\
\text { R Square }\end{array}$ & $\begin{array}{l}\text { Std. Error of } \\
\text { the Estimate }\end{array}$ & $\begin{array}{c}\text { R } \\
\text { Square } \\
\text { Change }\end{array}$ & $\begin{array}{c}\text { F } \\
\text { Change }\end{array}$ & df1 & df 2 & $\begin{array}{c}\text { Sig. F } \\
\text { Change }\end{array}$ & \\
\hline 1 & $0.343^{\mathrm{a}}$ & 0.118 & 0.114 & 1.901 & 0.118 & 30.936 & 1 & 232 & 0.000 & 1.961 \\
\hline
\end{tabular}

ANOVA ${ }^{\mathrm{a}}$

\begin{tabular}{llllllll}
\hline \multirow{2}{*}{ Model } & & $\begin{array}{c}\text { Sum of } \\
\text { Squares }\end{array}$ & df & Mean Square & F & Sig. \\
\hline 1 & Regression & 111.850 & 1 & 111.850 & 30.936 & $0.000^{\mathrm{b}}$ \\
\cline { 2 - 7 } & Residual & 838.799 & 232 & 3.616 & \\
\cline { 2 - 6 } & & & & & & & \\
& Total & 950.650 & 233 & & & \\
\hline
\end{tabular}

a. Dependent Variable: jobsearchhabits

b. Predictors: (Constant), Socialmedia

\begin{tabular}{|c|c|c|c|c|c|c|}
\hline \multicolumn{7}{|c|}{ Coefficients $^{\mathbf{a}}$} \\
\hline \multirow[b]{2}{*}{ Model } & & \multicolumn{2}{|c|}{$\begin{array}{l}\text { Unstandardised } \\
\text { Coefficients }\end{array}$} & \multirow{2}{*}{$\begin{array}{c}\begin{array}{c}\text { Standardised } \\
\text { Coefficients }\end{array} \\
\text { Beta }\end{array}$} & \multirow[b]{2}{*}{$\mathrm{t}$} & \multirow[b]{2}{*}{ Sig. } \\
\hline & & B & Std. Error & & & \\
\hline \multirow[t]{2}{*}{1} & (Constant) & 2.709 & 0.451 & & 6.006 & 0.000 \\
\hline & Socialmedia & 0.428 & 0.077 & 0.343 & 5.562 & 0.000 \\
\hline
\end{tabular}

a. Dependent Variable: jobsearchhabits

Source: own compilation 
As the Model Summary section of Table 1 shows, the $R$ value is 0.343 . The $R$ value represents the correlation value between the use of social media and the job search habits of the younger generations. The R Square value is 0.118 and the Adjusted R Square value is 0.114 . Since, the Adjusted R Square value is 0.114 , it can be concluded that the independent variable accounts for nearly $11 \%$ of the variation in the dependent variable. The ANOVA section of Table 1 illustrates that the F value is 30.936. Since the F statistic is significant at 0.000 it can be said that social media plays an important role in job search habits of younger generations. The Beta value is 0.343 at a significance level of 0.000 . It indicates that social media contributes significantly to job search habits of younger generations. The t value is 5.562 and the associated $\mathrm{p}$ value is 0.000 . As the $\mathrm{p}$ value is smaller than 0.05 it can be concluded that the independent variable reliability predicts the variation in the dependent variable and the relationship between them is significant.

The employer branding of companies also includes the development of the organisation's Internet profile. Young generations prefer to look at the website of the company of their choice, in many cases, decide to choose the company as their future job based on the website. Thus, the Internet profile of companies plays an important role in finding talented employees.

Table 2. Regression model of hypothesis 2

Model Summary ${ }^{b}$

\begin{tabular}{|c|c|c|c|c|c|c|c|c|c|c|}
\hline \multirow[b]{2}{*}{ Model } & \multirow[b]{2}{*}{$\mathrm{R}$} & \multirow[b]{2}{*}{ R Square } & \multirow[b]{2}{*}{$\begin{array}{l}\text { Adjusted R } \\
\text { Square }\end{array}$} & \multirow[b]{2}{*}{$\begin{array}{l}\text { Std. Error of } \\
\text { the Estimate }\end{array}$} & \multicolumn{5}{|c|}{ Change Statistics } & \multirow[b]{2}{*}{$\begin{array}{l}\text { Durbin- } \\
\text { Watson }\end{array}$} \\
\hline & & & & & $\begin{array}{l}\text { R Square } \\
\text { Change }\end{array}$ & F Change & df1 & df2 & $\begin{array}{c}\text { Sig. F } \\
\text { Change }\end{array}$ & \\
\hline 1 & $0.412^{\mathrm{a}}$ & 0.170 & 0.166 & 1.466 & 0.170 & 47.371 & & 232 & 0.000 & 1.870 \\
\hline
\end{tabular}

ANOVA ${ }^{a}$

\begin{tabular}{llllllll}
\hline \multirow{2}{*}{ Model } & & \multicolumn{2}{c}{$\begin{array}{c}\text { Sum of } \\
\text { Squares }\end{array}$} & df & Mean Square & F & Sig. \\
\hline 1 & Regression & 101.793 & 1 & 101.793 & 47.371 & $0.000^{\mathrm{b}}$ \\
\cline { 2 - 7 } & Residual & 498.536 & 232 & 2.149 & \\
\cline { 2 - 6 } & Total & 600.329 & 233 & & \\
& & & & & & \\
\end{tabular}

a. Dependent Variable: companyprofile

b. Predictors: (Constant), jobchoice

\begin{tabular}{|c|c|c|c|c|c|c|}
\hline \multicolumn{7}{|c|}{ Coefficients $^{\mathrm{a}}$} \\
\hline \multirow[b]{2}{*}{ Model } & & \multicolumn{2}{|c|}{$\begin{array}{c}\text { Unstandardised } \\
\text { Coefficients }\end{array}$} & \multirow{2}{*}{$\begin{array}{c}\begin{array}{c}\text { Standardised } \\
\text { Coefficients }\end{array} \\
\text { Beta }\end{array}$} & \multirow[b]{2}{*}{$\mathrm{t}$} & \multirow[b]{2}{*}{ Sig. } \\
\hline & & B & Std. Error & & & \\
\hline \multirow[t]{2}{*}{1} & (Constant) & 3.179 & 0.328 & & 9.694 & 0.000 \\
\hline & jobchoice & 0.399 & 0.058 & 0.412 & 6.883 & 0.000 \\
\hline
\end{tabular}

a. Dependent Variable: companyprofile

Source: own compilation 
As the Model Summary section of Table 2 shows, the $R$ value is 0.412 . The $R$ value represents the correlation value between use of company Internet profile and the job choice of younger generations. The R Square value is 0.170 and the Adjusted R Square value is 0.166. Since, the Adjusted R Square value is 0.166 , it can be concluded that the independent variable accounts for nearly $17 \%$ of the variation in the dependent variable. The ANOVA section of Table 2 illustrates that the F value is 47.371. Since the F statistic is significant at 0.000 it can be said that company Internet profile plays an important role in job choice of younger generations. The Beta value is 0.412 at a significance level of 0.000. It indicates that company Internet profile contributes significantly to job choice of younger generations. The t value is 6.883 and the associated $p$ value is 0.000 . As the $p$ value is smaller than 0.05 it can be concluded that the independent variable reliability predicts the variation in the dependent variable and the relationship between them is significant.

Based on the regression analyses presented above, we accept both of our hypotheses.

\section{Conclusion}

Theoretical part of this paper explains that the transitional crisis is influenced by different institutional, Generation $\mathrm{Z}$ is about to enter the job market and companies need to know how to reach them. According to Schroth (2019), 74\% of members of the $\mathrm{Z}$ generation will communicate digitally, and only $26 \%$ face-to-face. With the rapid and instant exchange of information, entertainment, gaming, dating, and mobility, the Internet and social media make up a huge part of people's daily lives. The labour market is an inevitable part of digitalisation, and companies have begun to recognise it (Mau and Kopischke, 2001). Based on our results, we conclude the following:

- The increasing use of the Internet and the spread of social media make it clear that companies have to make their job advertisements available online. The majority of our survey participants (79.5\%) classified themselves as more intensive social media users.

- The most used platforms are Facebook (34.4\%), LinkedIn (26.9\%), and Instagram $(12.4 \%)$. More and more small and large companies are using Facebook to recruit, as $63 \%$ of those surveyed have already received a job offer through it. LinkedIn is also very popular (47\%), which is a social media platform specifically designed to connect jobseekers with providers.

- Classic job searches such as advertisements in newspapers are becoming less popular due to digitalisation since only $3 \%$ of respondents chose that they would use this method. From this, we can also see that the role of social media is already essential in job search and companies need to innovate their recruitment processes.

- Respondents also frequently browse companies' websites, as $46.6 \%$ of respondents have already used it to inspect their potential future workplace.

- In addition to its widespread use and popularity, young people claim it is safe to look for a job on the Internet, but, in many cases, there is still room for improvement, as many complained about false job descriptions.

Summarising our research findings, we can state that there is a clear connection between the use of social media and the job search habits of the younger generations, for which it is worthwhile for companies to develop marketing in the future so that they are available on as many social media platforms as possible. Furthermore, the Internet profile of companies also has an impact on the choice of workplace for the younger generations, so companies need to be appealing and meaningful in every aspect in order to attract today's young people. 


\section{Acknowledgment}

The publication of this article was funded by the Pallas Athéné Foundations.

\section{References}

Bartosik-Purgat, M. (2019). Digital Marketing Communication from the Perspective of Individual Consumers: A Cross-Country Comparison. Entrepreneurial Business and Economics Review, 7(3), 205-220. https://doi.org/10.15678/EBER.2019.070311

Beard, T. R., Ford, G. S., Saba, R. P., \& Seals, R. A. (2012). Internet use and job search. Telecommunications Policy, 36(4), 260-273. doi:10.1016/j.telpol.2011.12.001

Bilan Y., Mishchuk, H., Roshchyk, I. \& Joshi, O. (2020). Hiring and retaining skilled employees in SMEs: problems in human resource practices and links with organizational success. Business: Theory and Practice, 21(2), 780-791. DOI: https://doi.org/10.3846/btp.2020.12750

Bilan, Y., Mishchuk, H., Samoliuk, N., \& Grishnova, O. (2019). ICT and Economic Growth: Links and Possibilities of Engaging. Intellectual Economics, 13(1). DOI: https://doi.org/10.13165/IE-19-13-1-07

Chapman, D. S., \& Webster, J. (2003). The Use of Technologies in the Recruiting, Screening, and Selection Processes for Job Candidates. International Journal of Selection and Assessment, 11(2-3), 113-120. doi:10.1111/1468-2389.00234

Datareportal.com (2020). Digital 2020 Global Digital Overview. Retrieved June 22, 2020 from https://datareportal.com/reports/digital-2020-global-digital- overview

Davison, H. K., Bing, M. N., Kluemper, D. H., \& Roth, P. L. (2016). Social Media as a Personnel Selection and Hiring Resource: Reservations and Recommendations. Social Media in Employee Selection and Recruitment, 15-42. doi:10.1007/978-3-319-29989$1 \_2$

Fertig, A. (2013). 6 Ways Recruiters Use LinkedIn to Headhunt. Retrieved July 18, 2020 from https://money.usnews.com/money/blogs/outside-voices-careers/2013/07/16/6-waysrecruiters-use-linkedin-to-headhunt

Hootsuite.com (2020). Social media statistics for social media managers. Retrieved June 22, 2020 from https://blog.hootsuite.com/social-media-statistics-for-social- media-managers

Yankow, J. J. (2017). Employed Job Search among Young Workers: Do Women Still Search Differently than Men in the Internet Age? International Advances in Economic Research, 23(2), 245-259. doi:10.1007/s11294-017-9633-0

Jansen, B. J., Jansen, K. J., \& Spink, A. (2005). Using the web to look for work. Internet Research, 15(1), 49-66. doi:10.1108/10662240510577068

Jobvite.com (2019). Job Seeker Nation. Retrieved June 22, 2020 from https://www.jobvite.com/wp-content/uploads/2019/04/2019_Job_Seeker_Nation.pdf

Karacsony, P. (2019). Generational Differences in Motivation at Work in Slovakian Small and Medium Sized Companies. Open Journal of social sciences. 7(3) 182-191.

Kluemper, D. H., \& Rosen, P. A. (2009). Future employment selection methods: evaluating social networking web sites. Journal of Managerial Psychology, 24(6), 567-580. doi:10.1108/02683940910974134

Lechman, E. (2018). Networks Externalities as Social Phenomenon in the Process ICT Diffusion. Economics and Sociology, 11(1), 22-43. doi:10.14254/2071- 789X.2018/11$1 / 2$

Lenart-Gansiniec, R., \& Sułkowski, Ł. (2020). Organizational learning and value creation in local governance: the mediating role of crowdsourcing. The Learning Organization, 27(4), pp. 321-335. 
Madia, S. A. (2011). Best practices for using social media as a recruitment strategy. Strategic HR Review, 10(6), 19-24. doi:10.1108/14754391111172788

Mau, W.-C., \& Kopischke, A. (2001). Job search methods, job search outcomes, and job satisfaction of college graduates: a comparison of race and sex. Journal of Employment Counseling, 38(3), 141-149. doi:10.1002/j.2161-1920.2001.tb00496.x

Mazurek, G., Korzyński, P., \& Górska, A. (2019). Social Media in the Marketing of Higher Education Institutions in Poland: Preliminary Empirical Studies. Entrepreneurial Business and Economics Review, 7(1), 117-133. https://doi.org/10.15678/EBER.2019.070107

McCrindle, M. \& Wolfinger, E. (2010). The ABC of XYZ. Understanding the Global Generations. University of New South Wales Press. ISBN:978-1742230351

Mičík, M., \& Mičudová, K. (2018). Employer Brand Building: Using Social Media and Career Websites to Attract Generation Y. Economics \& Sociology, 11(3), 171-189. doi:10.14254/2071-789x.2018/11-3/11

Montana, P. J., \& Petit, F. (2011). Motivating And Managing Generation X And Y On The Job While Preparing For Z: A Market Oriented Approach. Journal of Business \& Economics Research (JBER), 6(8). doi:10.19030/jber.v6i8.2459

Navickas, V., Grenčíková, A., \& Španková, J. (2019). The Use of Social Media Job Search. Mediterranean Journal of Social Sciences, 10(1), 17-26. doi:10.2478/mjss-2019-0002

Nicoli, N., \& Papadopoulou, E. (2017). TripAdvisor and reputation: a case study of the hotel industry in Cyprus. EuroMed Journal of Business, 12(3), 316-334. doi:10.1108/emjb-112016-0031

Nikodemska-Wołowik, A.M., Bednarz, J., \& Foreman, J.R. (2019). Trends in young consumers' behaviour - implications for family enterprises. Economics and Sociology, 12(3), 11-24. doi:10.14254/2071-789X.2019/12-3/1

Petschar, S., \& Zavrel, J. (2016). Candidate Experience in E-Recruiting. Wiesbaden: Springer Gabler. 91-107. ISBN:978-3-658-08895-8

Prensky, M. (2001). Digital Natives, Digital Immigrants Part 1. On the Horizon, 9(5), 1-6. doi:10.1108/10748120110424816

Saksiriruthai, S. (2018). Impact of media technology on wage changes: The case of Thailand. Journal of International Studies, 11(4), 69-78. doi:10.14254/2071- 8330.2018/11-4/5

Savković, M., Alčaković, S., \& Đorđić, N. (2016). Use of Internet in the Job Search Process: Gender Perspective. Proceedings of the International Scientific Conference - Sinteza doi:10.15308/sinteza-2016-31-35

Schroth, H. (2019). Are You Ready for Gen Z in the Workplace? California Management Review, 61(3), 5-18. doi:10.1177/0008125619841006

Slovensky, R., \& Ross, W. H. (2012). Should human resource managers use social media to screen job applicants? Managerial and legal issues in the USA. Info, 14(1), 55-69. doi:10.1108/14636691211196941

Stamolampros, P., Korfiatis, N., Kourouthanassis, P., \& Symitsi, E. (2018). Flying to Quality: Cultural Influences on Online Reviews. Journal of Travel Research, 58(3), 496-511. doi: $10.1177 / 0047287518764345$

Stoughton, J. W., Thompson, L. F., \& Meade, A. W. (2013). Examining Applicant Reactions to the Use of Social Networking Websites in Pre-Employment Screening. Journal of Business and Psychology, 30(1), 73-88. doi:10.1007/s10869-013-9333-6

Sullivan, J. (2013). The top 25 recruiting trends, problems, and opportunities for 2014. Retrieved June 22, 2020 from https://www.ere.net/the-top-25-recruiting-trendsproblems-and-opportunities-for-2014-part-2-of-2/

Suvankulov, F., Chi Keung Lau, M., \& Ho Chi Chau, F. (2012). Job search on the internet and its outcome. Internet Research, 22(3), 298-317. doi:10.1108/10662241211235662 
Swartz. L., Huff. S., \& Harper, J. (2017). Getting to know Gen-Z: how the pivotal generation is different than Millennials. Retrieved July 12, 2020 from http://www.millennialmarketing.com/wp-content/uploads/2016/12/FutureCast_ThePivotal-Generation-7.pdf

Victor, V., Thoppan, J. J., Fekete-Farkas, M., \& Grabara, J. (2019). Pricing strategies in the era of digitalisation and the perceived shift in consumer behaviour of youth in Poland. Journal of International Studies, 12(3), 74-91. doi:10.14254/2071-8330.2019/12-3/7 